\title{
Long-term effects of the 1998 coral bleaching event on reef fish assemblages
}

\author{
Kajsa C. Garpe ${ }^{1, *}$, Saleh A. S. Yahya ${ }^{1,2}$, Ulf Lindahl ${ }^{1}$, Marcus C. Öhman ${ }^{1}$ \\ ${ }^{1}$ Department of Zoology, Stockholm University, 10691 Stockholm, Sweden \\ ${ }^{2}$ Institute of Marine Sciences, University of Dar es Salaam, PO Box 668, Zanzibar
}

\begin{abstract}
Coral bleaching events constitute compound disturbances often resulting in coral death as well as successive degradation of the reef framework. The 1997/1998 El Niño Southern Oscillation (ENSO) was the most severe on record and affected coral reefs worldwide. The present study examined the response of fish assemblages in plots of transplanted coral before and after the 1998 bleaching. Multidimensional scaling ordinations (MDS) demonstrate significant changes in assemblage composition related to habitat alteration. Within-site variability increased with disturbance, the increase being most apparent following substrate erosion. The differences in long-term responses as opposed to short-term responses were striking. Six mo after coral death, total abundance as well as taxonomic richness had increased at one of the sites, but not the other, whereas 6 yr later, both measures had decreased significantly at both sites. Functional groups, with documented affiliations with coral, were significantly influenced by the habitat alteration. Herbivore abundance increased as an immediate response to bleaching, but was subsequently decimated in eroded habitat. The loss of structural complexity had major detrimental effects on the entire fish community. In conclusion, we present evidence of severe and long-lasting secondary impacts of a catastrophic bleaching event, with no apparent recovery. The discrepancies between short-term and long-term responses underline the importance of long-term monitoring of fish assemblages following habitat alteration.
\end{abstract}

KEY WORDS: Habitat structure · Disturbance · Coral degradation · Community ecology · Herbivores · Corallivores $\cdot$ Multivariate analyses $\cdot$ Global warming

\section{INTRODUCTION}

Coral bleaching, typically followed by coral death and erosion, represents a major and increasingly prevalent disturbance to coral reef ecosystems (Hughes et al. 2003, Hoegh-Guldberg 2004). The 1997/ 1998 El Niño Southern Oscillation (ENSO) was unprecedented, affecting seawater temperatures worldwide (McPhaden 1999). As a result, extensive bleaching occurred on nearly all coral reefs, followed by as much as $90 \%$ coral mortality at some localities (Wilkinson 2000). Given the structural properties of corals, bleaching and subsequent coral death may dramatically change the reef framework. Immediate effects of coral death include the reduction or loss of coral tissue, followed by rapid colonisation of turf algae (McCook 2001). With time, dead corals typically break into pieces, and coral rubble may, hence, become the dominant substratum (Riegl 2001). Subsequently, other sessile organisms such as macroalgae may take over, which could interfere with recruitment and subsequent recovery of the coral community (McCook 2001).

Habitat structure, defined as the physical and biological nature of the substratum (Jones 1991), plays a key role in major processes and interactions shaping fish assemblage composition, including recruitment (Öhman et al. 1998a, Syms \& Jones 2000) and postrecruitment processes such as competition and predation (Jones 1991, Hixon \& Beets 1993, Almany 2004). Correlations between both the abundance and diversity of reef fish and living corals have been described (e.g. Bell \& Galzin 1984, Öhman et al. 1998b, Garpe \& Öhman 2003, Halford et al. 2004). Consequently, coral disturbance would be expected to have secondary 
effects on associated fish communities (Jones \& Syms 1998).

The influence of coral degradation on fish has been examined in a number of studies following infestations of the coral-feeding starfish Acanthaster planci (e.g. Williams 1986, Sano et al. 1987), storm damage (Cheal et al. 2002, Halford et al. 2004) and experimental coral destruction (Sano et al. 1984, Lewis 1997, Syms 1998, Syms \& Jones 2000). Although considerable effects of a major coral bleaching event on associated fish communities can be anticipated, indirect habitat-related effects of bleaching still remain largely unexplored, and, while a handful of studies have considered wholespecies assemblages (Lindahl et al. 2001, Adjeroud et al. 2002, McClanahan et al. 2002b, Riegl 2002, Spalding \& Jarvis 2002, Jones et al. 2004, Sano 2004), others have been limited to a few taxa including damselfish (Wellington \& Victor 1985, Booth \& Beretta 2002), butterflyfish (Pratchett et al. 2004), gobies (Munday 2004), pufferfish (Guzman \& Robertson 1989) and filefish (Kokita \& Nakazono 2001).

The most significant aspect of habitat alteration following a severe disturbance may be the loss of structural complexity, which on coral reefs is typically related to coral cover. Structurally complex habitats typically support more abundant and species-rich reef fish communities than less complex habitats (e.g. Friedlander \& Parish 1998, Chittaro 2004, Gratwicke \& Speight 2005). There is increasing evidence that structural complexity exerts stronger influence on reef fish than coral cover per se (Lewis 1997, Öhman \& Rajasuriya 1998, Bergman et al. 2000). For example, dead coral habitat may continue to support abundant and diverse reef-fish communities providing that the dead coral structures retain their structural complexity (Lindahl et al. 2001). However, given the lack of coral recruitment and growth, erosion of the dead coral will most likely cause successive decline in structural complexity (e.g. Sano et al. 1987).

The importance of structural complexity implies that longer-term impacts of bleaching might be more dramatic to fish assemblages than the initial loss of live coral cover, as dead coral typically erode to rubble. For example, long-term studies have reported the decline of both fish abundance and species richness following mass coral die-off related to Acanthaster planci infestations (Sano et al. 1987) and storm damage (Halford et al. 2004). Given the anticipated increase in frequency and severity of temperature-related coral bleaching due to global warming (Hughes et al. 2003, Hoegh-Guldberg 2004), consideration of long-term responses of reef fish communities to widespread coral death is crucial.

The present study provides documentation on relatively long-term, as opposed to immediate, responses in fish communities to the 1997/1998 ENSO. We revis- ited experimental plots 6 yr after the bleaching event and compared fish-assemblage responses to those recorded by Lindahl et al. (2001) 6 mo after the disturbance. Given the poor post-bleaching recovery on these reefs (U. Lindahl pers. obs.), we predicted an alteration in community composition related to the reduction of complexity. It was further anticipated that the initial post-disturbance increase in fish abundance observed in 1998 (Lindahl et al. 2001) would be reversed and that the low-relief environment would support more variable fish assemblages with comparatively fewer individuals and taxa than both before and shortly after the 1998 bleaching.

\section{MATERIALS AND METHODS}

Study area. The study was carried out at Tutia Reef in Mafia Island Marine Park (MIMP), Tanzania $\left(7^{\circ} 40^{\prime} \mathrm{S}, 40^{\circ} 40^{\prime} \mathrm{E}\right)$. MIMP is situated $21 \mathrm{~km}$ from the African mainland, $60 \mathrm{~km}$ south of Dar es Salaam. The park was opened in 1995 and allows limited resource use. Tutia Reef is situated in the south-eastern area of the park, at the outer edge of the archipelago. The study sites were situated on the protected side of the reef, at a depth of $3 \mathrm{~m}$ at low tide, within a flat area covered by sand, coral rubble, rhodolites and patches of coral.

Fragments of the branching staghorn coral Acropora muricata (formerly $A$. formosa) were transplanted in 1995 into quadrates as an experiment on the rehabilitation of degraded coral reefs. The coral fragments were collected from naturally growing thickets in an area adjacent to the study site and were placed in 32 quadrate plots measuring $2.5 \times 2.5 \mathrm{~m}$ each (Lindahl 1998). Iron stakes and strings were used to demarcate the perimeter of the quadrates. Sixteen experimental plots were positioned in each of 2 sites situated $200 \mathrm{~m}$ apart (Fig. 1).

Habitat census. The character of the substratum, including live and dead coral, coral rubble and sand, was estimated in 1997 and 1998 by point-sampling on projections of slide photographs taken at several random positions in each plot. In addition, coral relief was estimated in 1998 and 2004 by placing 2 transect tapes, each with 5 regularly spaced $10 \mathrm{~cm}$ sections, across each plot. The height above the substrate of the tallest coral branch under each of the $10 \mathrm{~cm}$ sections was recorded, and the average of 10 such readings was used to represent the relief of each plot.

The density of live corals in the plots at the time of the first census (1997) ranged between 10 and $84 \%$ area cover, with an average of $33 \%( \pm 3.3 \mathrm{SE})$. Coral cover in the surrounding area was between 10 and $20 \%$, and consisted predominantly of branching thick- 


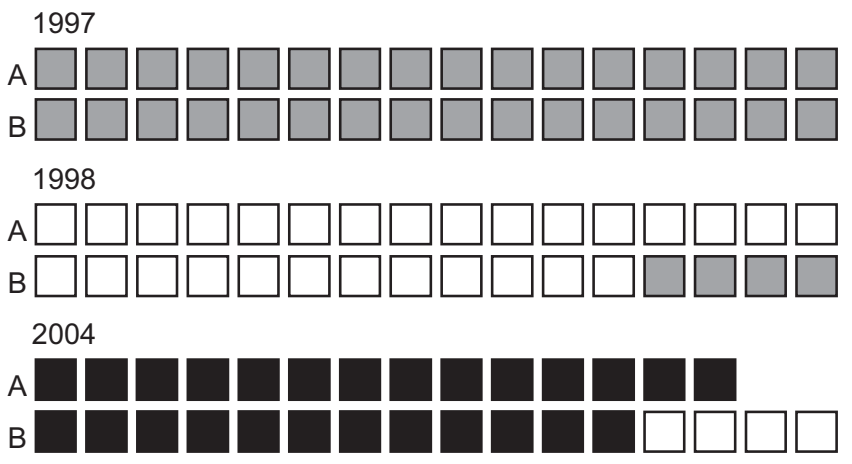

Fig. 1. Habitat structure in the experimental quadrates from 1997 to 2004. In 1997 the plots consisted of Acropora muricata, which had been transplanted in 1995. The 1998 mass bleaching event occurred 6 mo before the 1998 sampling $\square$ : live coral habitat; $\square$ : dead coral habitat; $\square$ : eroded coral habitat)

ets of the genus Acropora. Following the 1998 mass coral bleaching and mortality event, all corals had died in 28 plots, whereas the corals in the 4 remaining plots were much less affected (Fig. 1). These 4 plots will be referred to as $\mathrm{B}^{*}$. The average cover of live corals in $\mathrm{B}^{*}$ plots changed from $28 \%( \pm 8.7 \mathrm{SE})$ in 1997 to $25 \%$ $( \pm 7.0 \mathrm{SE})$ in 1998. Mean relief in dead coral plots 1998 was $9.9 \mathrm{~cm}( \pm 1.8 \mathrm{SE})$ at Site A and $14.2 \mathrm{~cm}( \pm 2.4 \mathrm{SE})$ at Site B. Mean relief in the coral plots resistant to bleaching was $15.5 \mathrm{~cm}( \pm 2.5 \mathrm{SE})$ in 1998. The 1998 bleaching event killed most of the corals in the surrounding area.

In 2004, all transplanted corals were dead (Fig. 1), as well as most of the nearby corals that had survived the 1998 bleaching event. Relief was significantly reduced in all plots where coral had suffered bleaching mortality, with mean relief being $3.6 \mathrm{~cm}( \pm 0.5 \mathrm{SE})$ at Site A and $3.3 \mathrm{~cm}( \pm 0.4 \mathrm{SE})$ at Site B. Relief in the $4 \mathrm{~B}^{*}$ plots that were dead, but not yet eroded was $14.3 \mathrm{~cm}$ $( \pm 3.2 \mathrm{SE})$, and was not significantly different from what it had been in 1998.

Fish census. Fishes were identified and counted by a stationary SCUBA diver using a method modified from Bohnsack \& Bannerot (1986). During the census, the diver rested at the seabed approximately $1 \mathrm{~m}$ from the edge of the plot and counted all fishes in the plot, including transient as well as stationary fishes, for a period of $10 \mathrm{~min}$ on each occasion. For the purpose of accuracy, and to reduce the problems encountered when fish were swimming in and out of the plot, the fish count was limited to $1 / 2$ (i.e. $3.1 \mathrm{~m}^{2}$ ) of each plot. Only fish occurring up to $1.5 \mathrm{~m}$ above the seabed were counted. Each count was replicated 3 times on different days. Individual fish were typically identified to species level. However, to avoid erroneous identification, we pooled certain species into easily identifiable higher taxa. The first set of censuses was completed in October 1997; the second, 1 yr later as part of a study carried out by Lindahl et al. (2001); and the concluding censuses for this study were completed in December 2004.

Functional groups. We examined a selected number of functional groups, focusing on their potential affiliation with live and dead corals and considering not only feeding behaviour, but also general habitat requirements (Froese \& Pauly 2005). Hence, fishes were divided into obligate corallivores, facultative corallivores, coral dwellers (excluding corallivores), benthic invertebrate feeders, roving herbivores and territorial herbivores. Coral dwellers included species known to associate closely with live coral and exhibiting high site fidelity, such as Plectroglyphidodon dickii, $P$. johnstonianus, Dascyllus spp. and Chromis spp., but excluded coral feeders (most of the coral dwellers were planktivores). Facultative corallivores included several species of the Chaetodontidae family, as well as Centropyge multispinis. Obligate corallivores comprised several chaetodontids, as well as Labrichthys unilineatus (Labridae) and Exallia brevis (Blennidae). Roving herbivores included fishes of the families Scaridae and Acanthuridae, as well as Cheilio inermis (Labridae). Territorial herbivores included damselfish (Pomacentridae) of the genera Stegastes and Chrysiptera, as well as Plectroglyphidodon lacrymatus. Among the surgeonfish and damselfish certain taxa ingest detritus rather than algae (Wilson \& Bellwood 1997, Choat et al. 2004). Since they nevertheless forage predominantly in turf, they were grouped with the herbivores. Benthic invertebrate feeders included a wide taxonomic variety, the majority belonging to the family Labridae.

Analyses. Fish abundance, taxonomic richness and functional group-specific abundances were tested for habitat, time and site differences using both parametric and non-parametric methods. $t$-tests for matched pairs and Wilcoxon signed ranks were used to make pairwise comparisons between sampling occasions. Mann-Whitney $U$-tests were used to compare independent samples such as site differences within sampling occasions. Where data were very scarce and dominated by null values, randomisation tests were applied (e.g. for obligate corallivores). When required, data were $\log (x+1)$ transformed prior to testing, and, where variances remained significantly unequal (F-test, p < 0.05) despite transformation, no further testing was performed. The statistical tests were performed to evaluate predicted effects of habitat alteration on total abundance and taxonomic richness, as well as for 5 functional groups with documented affiliation with habitat. Given the a priori relevance of both dependent and independent variables in this case, we considered corrections of multiple testing to be too conservative (Nakagawa 2004) and have therefore chosen to present original p-values. 
Multivariate non-metric multidimensional scaling ordination (MDS) was used to compare fish assemblages between sites and among habitats, as well as over 3 sampling periods. MDS plots were generated from a ranked similarity matrix based on the BrayCurtis similarity measure (Clarke 1993). Each point within the configuration represents the fish-assemblage composition in 1 plot in relation to the other plots. The closer 2 points are, the more similar are the associated fish assemblages. The degree to which the distances between all points in the plot accurately represent the similarity between them is quantified by the stress value. The plot accurately represents the similarities when the stress is $<0.1$. A stress value $>0.3$ indicates that the points are close to being randomly placed (Clarke 1993). All MDS ordinations were included only after being compared to the less stresssensitive hierarchical cluster analyses.

The multivariate pattern of the MDS ordination can be tested for significance using analysis of similarity (ANOSIM). This analysis generates a measure of the degree of separation of sites, $R$, which is close to 0 when similarities between and within sites are, on average, the same. An $R$-value of 1 indicates that all replicates within sites are more similar to each other than any replicate from different sites. Based on the assumption that the effect of habitat supersedes that of time (Lindahl et al. 2001), we used a 2-way, crossed ANOSIM to examine the effects of habitat and site. Samples from the B* plots of 1998 and 2004 ( $\mathrm{n}=8$ ) were excluded from this analysis, as they were not matched across site and included only limited numbers of replicates. Hence, in this analysis, the effect of habitat could not be separated from the potential effect of time. We have chosen not to present the p-values of the ANOSIM test as they are a direct function of the level of replication and, thus, may be misleading.

To measure the within-group variability, a value of relative dispersion was calculated using MVDISP. This procedure explores the relative multivariate variability within the rank similarity matrix underlying an ordination. In order to identify the taxa contributing the most to the dissimilarity between 2 fish assemblages in, e.g. different habitats, sites, or years, we used the similarity percentage procedure (SIMPER), which computes the average dissimilarity between pairs of inter-group samples $\left(\sum \delta_{i}\right)$. Based on the same similarity matrix as the other multivariate analyses, SIMPER identifies discriminating taxa, which are characterised by a consistent and high percent contribution $\left(\delta_{i} \%\right.$ to $\left.\sum \delta_{i}\right)$. The ratio between the average contribution to betweengroup dissimilarity and its standard deviation $\left(\delta_{i} / \mathrm{SD}\left[\delta_{i}\right]\right)$ is a predictor of how consistently the taxon is contributing to the overall dissimilarity. To downweight large numbers and account for variation, all variables were square root transformed prior to the multivariate analyses. One sample (2004, Site A) was omitted after being identified as an extreme outlier due to the presence of a single individual of an uncommon species. All multivariate analyses were carried out using PRIMER (Plymouth routines in multivariate ecological research), Version 6.1.2 (PRIMER-E).

\section{RESULTS}

\section{Fish-assemblage patterns}

Fish-assemblage composition differed in relation to habitat (Fig. 2a). The MDS reveals a gradual change, with minor overlaps from pre-bleach assemblages to assemblages sampled in 2004. The influence of habitat was apparent both at Site A (Fig. 2b) and at Site B (Fig. 2c). The 4 plots in which the corals survived the bleaching in $1998\left(\mathrm{~B}^{*}\right)$ are close to the 1997 live plot samples in the MDS. Similarly, the 2004 dead coral plots $\left(\mathrm{B}^{*}\right)$ cluster with the 1998 dead coral plots.

The patterns visible in the MDS plots were statistically supported by the ANOSIM. We found that fish assemblages were significantly different among habitats $(R=0.51)$, whereas the effect of site was insignificant $(R=0.19)$. On the initial sampling occasion, fish assemblages at Site A were not distinct from those at Site B $(R=0.28)$. However, Site A exhibited higher within-site variation than Site B.

Within-site variability increased with disturbance, particularly at Site B. At Site A, where variability was high already in 1997, there was no difference in relative dispersion between pre-bleach and post-bleach assemblages. The pattern of increased variability with degradation or disturbance is further supported by higher relative dispersion values in 1998 dead coral plots at both Site A (1.06) and B (0.76), compared to the $\mathrm{B}^{*}$ plots where corals remained alive (0.56). Similarly, in 2004, relative dispersion values were higher in eroded coral habitat at both Site A (1.50) and B (1.34) than in the $\mathrm{B}^{*}$ plots containing dead coral (0.61).

\section{Fish abundance and taxonomic richness}

Mass coral bleaching and subsequent mortality affected fish abundance and taxonomic richness. Average fish abundance differed among the 3 habitats (Fig. 3a). However, the nature of the disturbance effect appeared to be site specific. At Site B, dead coral habitat supported ca. $60 \%$ more fish than live coral habitat. As predicted, fish numerical abundance in the eroded habitat was low at both sites. Exploring fish abundance over time provides additional information (Fig. 3b). Ini- 

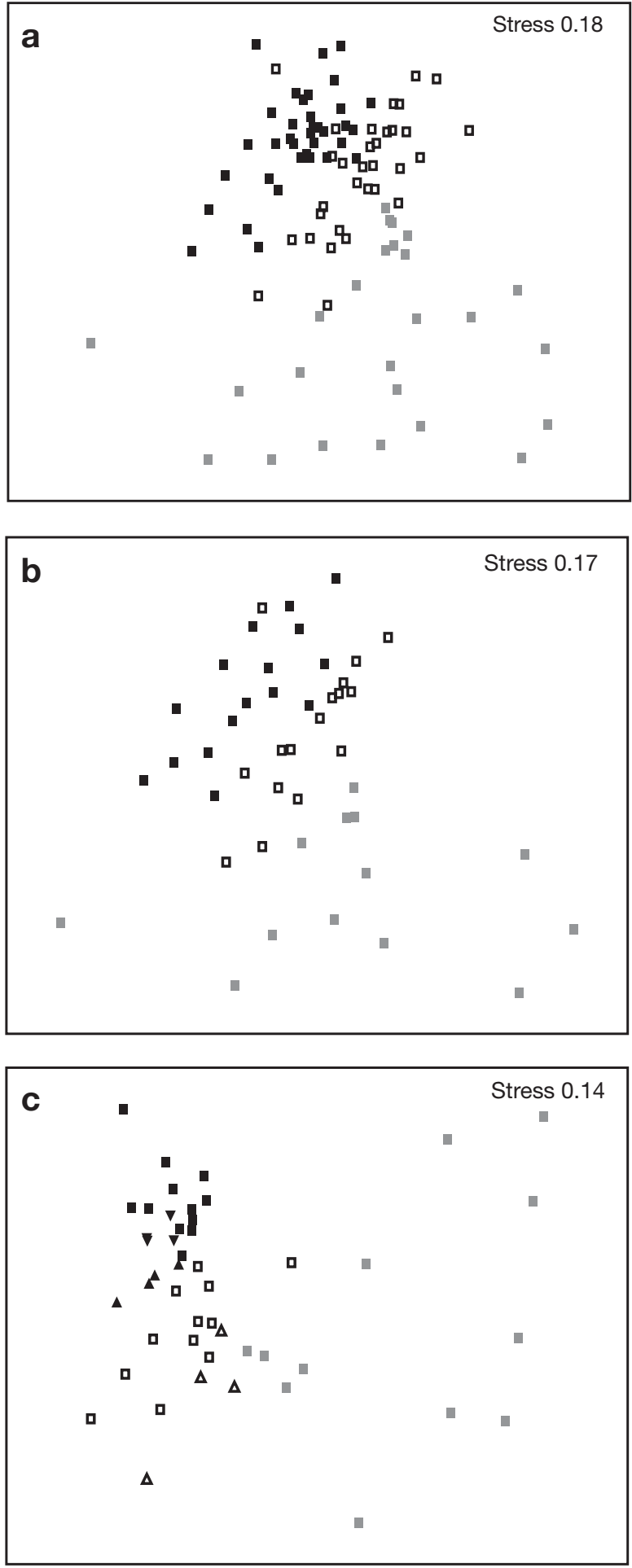

Fig. 2. Non-metric multidimensional scaling ordination of fishassemblage composition from 1997 to 2004, including 91 taxa (a) at both sites in relation to habitat, (b) at Site A in relation to habitat and (c) at Site B in relation to habitat and time. Analyses were performed on Bray-Curtis dissimilarities of squareroot-transformed data ( $\mathbf{\square}$ : live coral; $\square$ : dead coral; $\varpi$ : eroded coral $_{;} \mathbf{\nabla}$ : live B* plots in 1997 prior to bleaching; $\mathbf{\Delta}^{*}$ : live B* plots in 1998 after bleaching; $\Delta$ : dead non-eroded $B^{*}$ plots in 2004) tially, fish abundance did not differ significantly between Sites A and B. Following the bleaching and subsequent coral mortality, a $71 \%$ increase in total fish abundance (Wilcoxon, $\mathrm{n}=12, \mathrm{p}=0.02$ ) was recorded for Site B. The equivalent pattern was not apparent at Site A. Mean fish abundance also increased at the B* plots from 1997 to 1998 (pairwise $t$-test, $\mathrm{n}=4, \mathrm{p}=0.05$ ). Following the reduction in complexity, abundance decreased significantly at both Site A (Wilcoxon, $\mathrm{n}=$ $14, p=0.001)$ and $B(n=12, p=0.002)$ to levels below those of the $2004 \mathrm{~B}^{*}$ plots in which structural complexity remained similar to that in 1998 (Mann-Whitney, $\left.\mathrm{n}_{1}=4, \mathrm{n}_{2}=12, \mathrm{p}=0.001\right)$.

The number of recorded taxa over the 3 sampling occasions was 91. In response to the bleaching and subsequent coral death, the mean number of recorded taxa followed the same trend as fish abundance (Fig. 3c,d). We recorded a $60 \%$ increase in the number of taxa at Site B following coral bleaching (Wilcoxon, $\mathrm{n}=12, \mathrm{p}=0.002)$. Contrary to numerical abundance, the increase in taxa at $\mathrm{B}^{*}$ between 1997 and 1998 was not significant (pairwise $t$-test, $\mathrm{n}=4, \mathrm{p}=0.08$ ). Following the erosion of the substrate, we recorded significant decreases at both Site A (Wilcoxon, $\mathrm{n}=14, \mathrm{p}=$ 0.002 ) and Site B (Wilcoxon, $n=12, p=0.002$ ). The accumulated number of taxa at each site ranged between 29 and 65. For Sites A and B the maximum numbers of taxa were recorded in dead coral habitat in 1998 (52 and 62 taxa, respectively), and the minimum numbers of taxa were counted in 2004 in the eroded coral habitat (29 and 31 taxa at Sites A and B, respectively).

\section{Functional groups}

Functional groups, with documented affiliations with coral, were significantly influenced by habitat alteration. Group-specific responses to habitat alteration are illustrated in Fig. 4. The abundance of coral dwellers was lower in dead coral habitat than in live (Fig. 4a). Furthermore, the bleach-resistant coral plots $\left(\mathrm{B}^{*}\right)$ supported twice as many coral dwellers in 1998 as they did prior to the mass bleaching (Fig. 4b). This result is, however, not statistically significant. In 2004, when the $\mathrm{B}^{*}$ plots were dead but not eroded, coral dwellers had been significantly reduced (pairwise $t$ test, $\mathrm{n}=4, \mathrm{p}=0.004)$. Six years after the bleaching, and with the subsequent loss of complexity, the abundance of coral dwellers in eroded coral habitat was reduced to naught.

Facultative coral feeders did not respond with decreased abundances to coral death. On the contrary, they increased following coral death and subsequently decreased following coral erosion (Fig. 4c,d). Although 

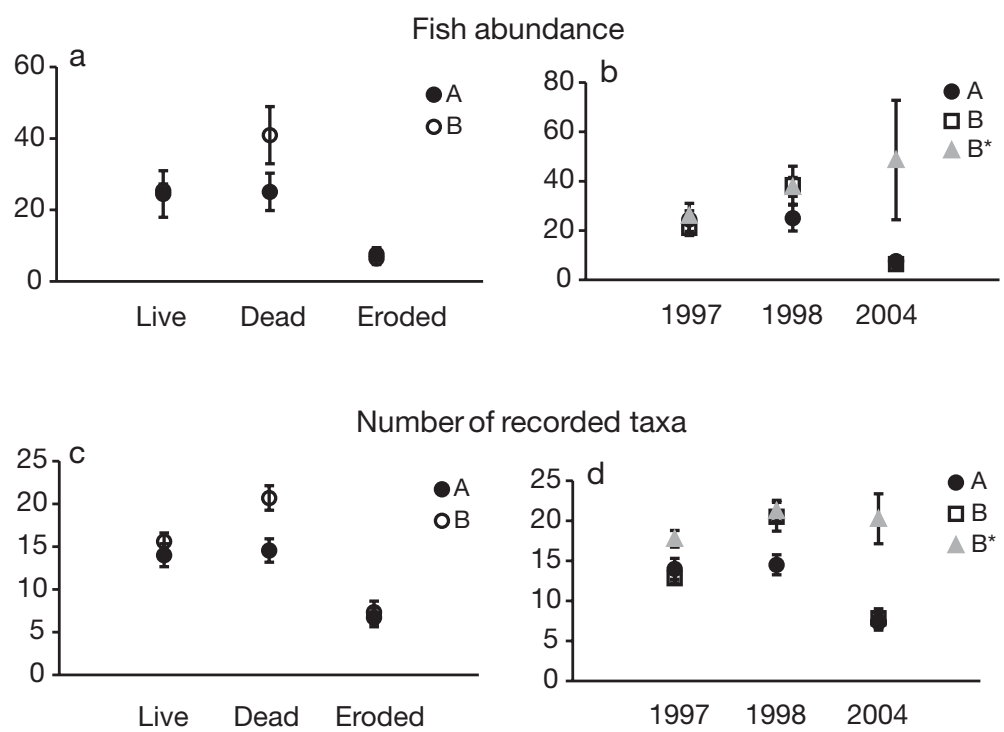

Fig. 3. (a,b) Mean fish numerical abundance $( \pm \mathrm{SE})$ and $(\mathrm{c}, \mathrm{d})$ species richness $( \pm \mathrm{SE})$ in relation to habitat structure and as a response to habitat changes occurring over time (•: Site $A_{;}$: Site $B_{;} \Delta_{\text {: }} B^{*}$ plots)

relatively uncommon at all times, and therefore difficult to assign statistical evidence, the 1998 live coral plots $\left(\mathrm{B}^{*}\right)$ supported higher numerical abundance of this functional group than the same plots in 1997. However, the
1998 dead plots sustained equally high numbers. In 2004 facultative coral feeders were absent from all plots. The response to habitat alteration from live to dead coral cover was somewhat equivocal for the obligate coral feeders (Fig. 4e,f). This group increased at Site B after the death of the coral. However, this result was weakened by the few appearances and the high among-sample variability. As predicted, the eroded coral habitat was devoid of obligate coral feeders.

Roving herbivores responded clearly to the habitat alteration. At the initial examination of the fish assemblages in 1997, Site B was more frequently visited by roving herbivores than Site A (MannWhitney, $\mathrm{n}=16, \mathrm{p}=0.04$ ). Following coral bleaching, roving herbivores increased significantly at both Site A (Wilcoxon, $\mathrm{n}=16, \mathrm{p}=0.001$; Fig. $4 \mathrm{~g})$ and $\mathrm{B}(\mathrm{n}=12$, $p=0.002$; Fig. $4 \mathrm{~h}$ ). The increase was highest at Site B. When the coral had eroded herbivores had significantly decreased at both Site A (Wilcoxon, $\mathrm{n}=14, \mathrm{p}=0.05)$ and $\mathrm{B}(\mathrm{n}=12, \mathrm{p}=0.002)$. The $4 \mathrm{~B}^{*}$ plots supported abundances in 2004 that were not significantly different from those of 1998

Table 1. Discriminating taxa for between-group dissimilarity identified by the similarity percentage procedure analyses. These taxa were characterised by a high percent contribution $\left(\delta_{\mathrm{i}} \%\right)$ to the overall between-group dissimilarity $\left(\sum \bar{\delta}_{\mathrm{i}}\right)$. The ratio between the average contribution to between-group dissimilarity and its standard deviation $\left(\bar{\delta}_{\mathrm{i}} / \mathrm{SD}\left[\delta_{\mathrm{i}}\right]\right)$ is a predictor of how consistently a taxon contributes to the overall dissimilarity. We only included taxa for which $\bar{\delta}_{\mathrm{i}} \%>5.0$ and $\bar{\delta}_{\mathrm{i}} / \mathrm{SD}\left(\delta_{\mathrm{i}}\right)>1.30($ Acanth: Acanthuridae; P. lacrym: Plectroglyphidodon lacrymatus; P. dickii: Plectroglyphidodon dickii; D. carn: Dascyllus carneus; Labr. spp: 6 unidentified labrid species; $P$. hexa: Pseudocheilinus hexataenia; arrows: dissimilarity was due to a comparatively higher [个] or lower $[\downarrow]$ abundance in the latter group)

\begin{tabular}{|c|c|c|c|c|c|c|c|c|c|}
\hline $\begin{array}{l}\text { Group } \\
\text { comparison }\end{array}$ & Effects & $\sum \bar{\delta}$ & Scaridae & Acanth. & P. lacrym. & $\begin{array}{l}\bar{\delta}_{\mathrm{i}} \%\left(\bar{\delta}_{\mathrm{i}} / \mathrm{SD}\left[\delta_{\mathrm{i}}\right]\right) \\
\quad \text { P. dickii }\end{array}$ & D. carn. & Labr. spp. & P. hexa. \\
\hline 1997 A-1997 B & Site & 55.9 & & & & $10.4(1.3) \uparrow$ & & & \\
\hline 1998 A-1998 B & Site & 57.3 & $6.8(1.3) \uparrow$ & $9.1(1.5) \uparrow$ & $6.5(1.3) \downarrow$ & & & & \\
\hline $1997 B^{*}-1998 B^{*}$ & Time & 41.5 & & & & & $9.3(1.7) \downarrow$ & & \\
\hline $1998 \mathrm{~B}-2004 \mathrm{~B}^{*}$ & Time & 52.7 & $5.3(1.4) \downarrow$ & & & & & & \\
\hline $1998 B^{*}-1998$ B & $\begin{array}{l}\text { Habitat } \\
\text { (live vs. dead coral) }\end{array}$ & 51.4 & $5.5(1.3) \uparrow$ & $5.1(1.6) \uparrow$ & & $10.7(3.1) \downarrow$ & & & \\
\hline $2004 B^{*}-2004$ B & $\begin{array}{l}\text { Habitat } \\
\text { (dead vs. eroded coral) }\end{array}$ & 70.5 & $8.0(1.7) \downarrow$ & $9.5(1.6) \downarrow$ & $6.2(1.8) \downarrow$ & & & & \\
\hline 1997 A-1998 A & $\begin{array}{l}\text { Time \& Habitat } \\
\text { (live vs. dead coral) }\end{array}$ & 63.7 & $7.4(1.4)^{\uparrow}$ & & $6.5(1.3)^{\uparrow}$ & & & & \\
\hline $1997 B^{a}-1998$ B & $\begin{array}{l}\text { Time \& Habitat } \\
\text { (live vs. dead coral) }\end{array}$ & 56.4 & $9.7(1.9)^{\uparrow}$ & $7.6(1.6) \uparrow$ & & $9.8(2.2) \downarrow$ & & & \\
\hline $1998 \mathrm{~B}^{*}-2004 \mathrm{~B}^{*}$ & $\begin{array}{l}\text { Time \& Habitat } \\
\text { (live vs. dead coral) }\end{array}$ & 54.5 & & & & $10.0(3.3) \downarrow$ & & & \\
\hline $1998 \mathrm{~A}-2004 \mathrm{~A}$ & $\begin{array}{l}\text { Time \& Habitat } \\
\text { (dead vs. eroded coral) }\end{array}$ & 77.2 & $8.1(1.4) \downarrow$ & & & & & $9.3(1.5) \downarrow$ & $7.0(1.6) \downarrow$ \\
\hline 1998 B-2004 B & $\begin{array}{l}\text { Time \& Habitat } \\
\text { (dead vs. eroded coral) }\end{array}$ & 74.0 & $9.4(1.6) \downarrow$ & $10.9(1.6) \downarrow$ & $6.6(1.3) \downarrow$ & & & $5.8(2.0) \downarrow$ & $7.0(2.4) \downarrow$ \\
\hline
\end{tabular}



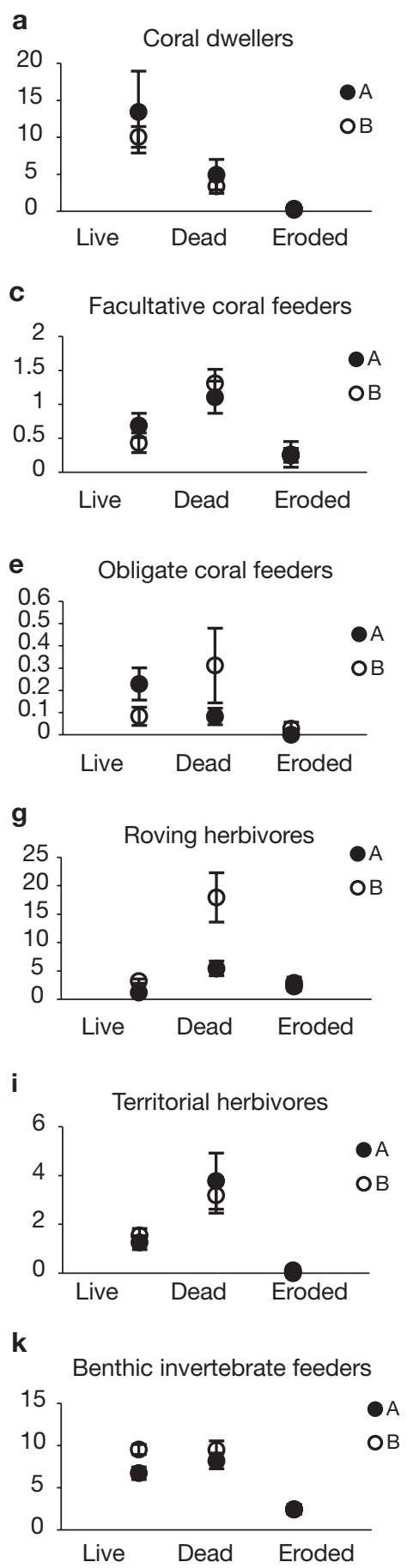

Fig. 4. Mean abundance $( \pm \mathrm{SE})$ of each of 6 functional groups in relation to habitat structure and as a response to habitat changes occurring over time (๑: Site $A_{i} \square$ : Site $B_{i} \Delta$ : $B^{*}$ plots) respectively), and their abundance in dead coral habitat was twice that in the live coral habitat. Territorial herbivores were as few in the 1998 live coral habitat as in the 1997 live coral habitat. This functional group was entirely missing in the 2004 eroded coral habitat, whereas the abundance in dead non-eroded coral ( $\left.\mathrm{B}^{*}\right)$ in 2004 was similar to that of dead noneroded coral in 1998. Benthic invertebrate feeders were not severely affected by the alteration from live to dead coral habitat (Fig. 4k,1). However, their abundance was dramatically reduced in the eroded coral habitat at both Site A (Wilcoxon, $\mathrm{n}=14$, $p=0.001)$ and $B(n=12, p=0.002)$.

\section{Discriminating taxa}

SIMPER examines the mean contribution as well as the consistency of contribution by each taxon to the overall dissimilarity between 2 treatment groups. We identified the best discriminator taxon for the short-term response to coral bleaching at Site B to be Plectroglyphidodon dickii, a typical coral dweller (Table 1). This species contributed largely and consistently to the overall dissimilarity between these 2 groups. $P$. dickii was further the foremost contributor to the differences observed between live and dead coral plots in 1998, as well as between live 1998 and dead 2004 plots (B*). Three herbivorous taxa, Scaridae, Acanthuridae and $P$. lacrymatus, were also identified as being important discriminators. These herbivores all exhibited greater abundance in dead coral habitats than in live and eroded coral habitats. The alteration in community composition following the transition from dead to eroded coral habitat could, to some extent, be contributed to a reduction in the above-mentioned herbivores as well as to a decrease in benthic invertebrate feeders such as Labridae species and Pseudocheilinus hexataenia.

\section{DISCUSSION}

dead coral plots at Site B. The response of territorial roving herbivores (Fig. 4i,j). Territorial herbivores increased at both Site A and B following coral bleaching and death (Wilcoxon, $\mathrm{n}=12, \mathrm{p}=0.04$ and $\mathrm{p}=0.06$,
Habitat structure plays a fundamental role in determining the structure of reef fish communities (Jones \& Syms 1998). Consequently, disturbance of key habitat 
components would be expected to influence associated fish assemblages. Natural disturbances are recurring features of the reef ecosystem. They are commonly limited to single reefs or, at the most, to reef areas on a regional scale (e.g. Sano et al. 1987, Hart et al. 1996, Cheal et al. 2002, Halford et al. 2004). The 1997/1998 coral bleaching event was unique in that it affected coral reefs in all tropical seas and, hence, became the most extensive cause of coral mortality on record (Hoegh-Guldberg 2004). Surprisingly, there is still only limited information on the secondary effects on associated communities. To date, only a handful of studies have considered whole fish assemblages, and they have so far been limited to short-term effects (Lindahl et al. 2001, Riegl 2002, Spalding \& Jarvis 2002, Sano 2004, but see McClanahan et al. 2002b, Jones et al. 2004). In the present study, we demonstrated how the impact of the bleaching event remained severe $6 \mathrm{yr}$ after the disturbance. We will refer to this response as being long term, the meaning of which will be relative, as compared to the short term response observed 6 mo after the disturbance. We recorded clear differences in individual abundance and taxonomic richness before and after coral death, before and after substrate erosion, and between dead and eroded habitat within the same sampling occasions. In addition, we revealed apparent dissimilarities in long-term responses as opposed to short-term responses.

Corals are the main structural components of most reefs, and, consequently, a change in coral cover is expected to influence coral-associated fish communities. Numerous studies have identified coral cover as the most important habitat factor regulating fish populations (e.g. Chabanet et al. 1997, Garpe \& Öhman 2003, Halford et al. 2004), while others have failed to detect such relationships (Roberts \& Ormond 1987, Booth \& Beretta 1994, Lecchini et al. 2005). How fish assemblages respond to coral degradation may depend on the magnitude of the disturbance, the initial coral cover, as well as the strength of the relationship between fish and corals at the time of the disturbance. Syms (1998) reported no major differences in fishassemblage composition over the 21 mo following a $21 \%$ reduction in coral cover. Further, he reported a mere $10 \%$ fish-assemblage change following 40 to $50 \%$ reduction in coral cover. In comparison, fish assemblages in the experimental plots of this study exhibited significant responses to the total reduction of an initial $33 \%$ coral cover. Six months after the disturbance, fish numbers had increased, but, by the time the coral had eroded and structural complexity had been severely reduced, all taxa and functional groups had decreased and total abundance and taxonomic richness had reached well below pre-perturbation levels. Similar results of significant decreases in numer- ous fish taxa have been recorded in the few studies that have monitored responses to coral degradation over relatively long periods of time (8 to $10 \mathrm{yr}$; Sano et al. 1987, Halford et al. 2004, Jones et al. 2004).

We recorded an overall decrease in fish numbers 6 yr after the coral mortality event, with certain taxa being more affected than others. Species-specific changes following habitat degradation have typically been related to the degree of specialisation (e.g. Öhman et al. 1998b, Munday 2004). In the present study, coral death caused a reduction of coral-associated species as well as an increase in transient taxa with wider resource requirements. Among the coral dwellers and corallivores, most taxa share well-documented associations with live coral habitat (e.g. Bouchon-Navaro \& Bouchon 1989, Allen 1991, Ault \& Johnson 1998, Cadoret et al. 1999, Garpe \& Öhman 2003, Bozec et al. 2005). As predicted, coral dwellers were less abundant in dead coral habitat than in live coral habitat, and both coral dwellers and coral feeders were absent from all eroded plots. In fact, the coral-dwelling Plectroglyphidodon dickii was identified as a discriminating species for the habitat alteration from live to dead coral. The sensitivity of $P$. dickii to coral degradation has previously been demonstrated (Wass 1987, Dawson-Shepherd et al. 1992), and, in accordance, other typical coral dwellers, including $P$. johnstonianus and Pomacentrus molluccensis, have been found to decline following coral degradation (Lewis 1997, Booth \& Beretta 2002, Spalding \& Jarvis 2002). Although rather uncommon, the abundance of $P$. johnstonianus also decreased significantly in this study. Similarly, there is substantial evidence of the detrimental effects of coral degradation on the abundance and diversity of coral feeding taxa (Sano et al. 1984, 1987, Williams 1986, Lewis 1997, Kokita \& Nakazono 2001, McClanahan et al. 2002b, Spalding \& Jarvis 2002, Halford et al. 2004, Sano 2004). Conversely, Pratchett et al. (2004) found no decrease in the abundance of butterflyfish, but nevertheless demonstrated sublethal alterations in physiological condition, possibly affecting abundances in a longer temporal perspective.

Algal growth, which may be directly related to disturbance (Connell 1997, McManus \& Polsenberg 2004), constitutes an important process in reef ecosystem dynamics. Following the loss of live tissue, coral skeletons are rapidly covered in turf algae (McCook 2001). Although difficult to quantify, due to the high turnover, the increase in algal abundance and productivity may be substantial (McClanahan et al. 2002b, Spalding \& Jarvis 2002, Halford et al. 2004), resulting in enhanced food resources for taxa feeding on algae. Consequently, coral mortality may have implications for herbivores as well, and, accordingly, they were primarily responsible for the recorded overall increase in 
fish abundance in the coral plots following coral death. Given their large home ranges (Hart et al. 1996) and their rapid response to disturbance, as well as the limited size of our coral plots and their proximity to continuous reef, we believe that the observed increase in herbivores 6 mo after the bleaching was largely due to redistribution or increased feeding ranges. Hart et al. (1996) suggested that roving herbivores should be able to benefit from sudden increases in turf algae, and a similar increase in herbivores was noted following an outbreak of Acanthaster planci (Wass 1987). However, contradicting results have also been presented (Hart et al. 1996, Williams 1986, Riegl 2002, Spalding \& Jarvis 2002), and no general consensus has yet emerged on fish-algae interactions on coral reefs following coral death.

While the short-term effects of coral degradation on herbivores included an increase in density, the longterm effect was the opposite. Six years after the bleaching, herbivores were almost absent from eroded plots, while still common in structurally complex dead plots. In accordance, Garpe \& Öhman (2003) discovered that $49 \%$ of the variation in the abundance of Scaridae, the most common family of roving herbivores, was attributed to branching structures, both living and dead. Notably, and in addition to changes in food availability following coral mortality, herbivore abundance may respond to the effects of disturbanceinduced reduction of structural complexity. In general, structurally complex reef habitats support both richer and more abundant fish communities than less complex habitats (e.g. Friedlander \& Parrish 1998, Öhman \& Rajasuriya 1998, Chittaro 2004, Gratwicke \& Speight 2005). Consequently, the loss of structural complexity is typically accompanied by a reduction in fish numbers. For example, Sano et al. (1984) found that the structural collapse of dead Acropora led to significant decreases in species diversity and numbers of individual fishes in the corals. In our plots, abundance and taxonomic richness were initially correlated to structural complexity (Lindahl et al. 2001), and, as the corals were fragmented, both of these aggregate measures decreased. Given this correlation, the recorded difference in relief between Sites A and B may, at least in part, explain the discrepancy in aggregate measures between sites in 1998. In 2004, when erosion had declined in plots subjected to the 1998 bleaching, both sites exhibited equally low fish abundance and taxonomic richness.

Habitat disturbances commonly increase the variability of associated communities (Warwick \& Clarke 1993). In MDS ordinations this variability is expressed as increased dispersion among points from samples taken at disturbed sites relative to less-disturbed sites (Dawson-Shepherd et al. 1992, Öhman et al. 1997,
Garpe \& Öhman 2003). Likewise, our results demonstrate how within-site community variability increased in response to the coral bleaching event. It is noteworthy that the increased dispersion related to the reduction of structural complexity was more prominent than that related to coral death, indicating that loss of structure was a more fundamental habitat alteration than loss of live coral tissue. The sequential increase in disturbance was more prominent at Site B, whereas at Site A fish assemblages were comparatively variable already in 1997. At Site A, a spawning population of Pseudobalistes flavimarginatus was present on all sampling occasions. $P$. flavimarginatus establish territories in which they aggressively chase off other fishes approaching nesting sites (Gladstone 1994). The resulting competition for space may have impacted fish-habitat interactions, increased variability and, consequently, influenced response to habitat alteration.

In addition to habitat structure, time was an important aspect of this study that might have influenced fish community structure. The magnitude of temporal variation in reef fish community composition remains debated. Sale et al. (1994) demonstrated variation in assemblage structure over a time period of $9 \mathrm{yr}$. Syms (1998) suggested that strong temporal variation may, in fact, overrule the effects of moderate disturbance. However, other workers have conversely reported inter-annual variation to be generally insignificant (e.g. Sano 2000, Halford et al. 2004). Although, the 2 factors were confounded in the multivariate tests, we argue that intense disturbance in this case exerted stronger influence on fish assemblages than temporal fluctuations. This conclusion is based on the fact that fish assemblages sampled in 1998 in the 4 out of 32 plots that resisted bleaching (Lindahl et al. 2001) were more similar to those in live coral plots prior to bleaching than to those of contemporary dead coral plots. A similar pattern was observed in 2004 when the same 4 plots were dead but not eroded. In support of the apparent multivariate patterns, aggregate measures of the full species assemblage, as well as functional group abundance, similarly responded to habitat rather than to time.

In conclusion, our results add to the existing work, suggesting that habitat structure influences fishassemblage composition on coral reefs (e.g. Friedlander \& Parrish 1998, Jones \& Syms 1998, Öhman \& Rajasuriya 1998, Syms \& Jones 2000, Garpe \& Öhman 2003, Chittaro 2004) and that habitat alteration may have extensive effects on associated fish communities (cf. Sano et al. 1984, 1987, Sano 2000, 2004, Williams 1986, Wass 1987, Lewis 1997, Syms 1998, Riegl 2002, McClanahan et al. 2002b, Halford et al. 2004). The apparent discrepancies between the short- and comparatively long- 
term responses evident in this study, in addition to the documented longevity of many reef fishes (Choat \& Robertson 2002), as well as an increasing body of evidence that potential recovery of coral assemblages occurs over a decade or more (Ninio et al. 2000, Sano 2000, Halford et al. 2004), call for long-term studies of natural and experimental habitat alteration and subsequent recovery patterns in coral reef fish communities. Six years after the 1998 mass bleaching event, there were no signs of habitat recovery, either in our plots or on the continuous reef nearby, and fish assemblages were significantly altered, with low individual abundance and taxonomic richness. Hence, it appears that widespread catastrophic bleaching events may have long-term effects on associated fish fauna and that the recovery of fish communities following such events is directly related to habitat recovery and may only occur over decades or more. Depending on factors such as levels of chronic stress, connectivity and ecosystem resilience, the bleaching-induced habitat alteration could, in fact, remain, causing a permanent shift in fish distribution patterns, which, in turn, may have implications on a range of functional interactions affecting overall ecosystem dynamics (Nyström et al. 2000, McClanahan et al. 2002a, Hughes et al. 2003, 2005).

Acknowledgements. We thank Mafia Island Marine Park, the WWF and P. Byrnes at Kinasi Lodge for providing logistic support. Special thanks are directed to K. R. Clarke and J. O. Persson for statistical guidance. B. Crona, as well as 3 anonymous reviewers, provided constructive advice on the manuscript. This study was part of a large-scale project investigating the ecological effects of coral bleaching in the Indian Ocean. This work was financed by the Marine Science for Management research programme (MASMA/WIOMSA), the World Conservation Society and the Sida/SAREC Bilateral Marine Science Programme between Sweden and Tanzania for research in marine zoology.

\section{LITERATURE CITED}

Adjeroud M, Augustin D, Galzin R, Salvat B (2002) Natural disturbances and interannual variability of coral reef communities on the outer slope of Tiahura (Moorea, French Polynesia): 1991 to 1997. Mar Ecol Prog Ser 237: 121-131

Allen GR (1991) Damselfishes of the world. Mergus Publishers, Melle

Almany GR (2004) Does increased habitat complexity reduce predation and competition in coral reef fish assemblages? Oikos 106:275-284

Ault TR, Johnson CR (1998) Spatially and temporally predictable fish communities on coral reefs. Ecol Monogr 68: 25-50

Bell JD, Galzin R (1984) Influence of live coral cover on coral reef fish communities. Mar Ecol Prog Ser 15:265-274

Bergman KC, Öhman MC, Svensson S (2000) Influence of habitat structure on Pomacentrus sulfureus, a western Indian Ocean reef fish. Environ Biol Fish 59:243-252

Bohnsack JA, Bannerot SP (1986) A stationary visual cen- sus technique for quantitatively assessing community structure of coral reef fishes. NOAA Tech Rep NMFS 41: $1-15$

Booth DJ, Beretta GA (1994) Seasonal recruitment, habitat associations and survival of pomacentrid reef fish in the US Virgin Islands. Coral Reefs 13:81-89

Booth DJ, Beretta GA (2002) Changes in a fish assemblage after a coral bleaching event. Mar Ecol Prog Ser 245: 205-212

Bouchon-Navaro Y, Bouchon C (1989) Correlations between chaetodontid fishes and coral communities of the Gulf of Aquaba (Red Sea). Environ Biol Fish 25:47-60

Bozec YM, Dolédec S, Kulbicki M (2005) An analysis of fish-habitat associations on disturbed coral reefs: chaetodontid fishes in New Caledonia. J Fish Biol 66:966-982

Cadoret L, Adjeroud M, Tsuchiya M (1999) Spatial distribution of chaetodontid fish in coral reefs of the Ryukyu Island, southern Japan. J Mar Biol Assoc UK 79:725-735

Chabanet P, Ralambondrainy H, Amanieu M, Faure G, Galzin R (1997) Relationships between coral reef substrata and fish. Coral Reefs 16:93-102

Cheal AJ, Coleman G, Delean S, Miller I, Osborne K, Sweatman H (2002) Responses of coral and fish assemblages to a severe but short-lived tropical cyclone on the Great Barrier Reef, Australia. Coral Reefs 21:131-142

Chittaro PM (2004) Fish-habitat associations across multiple spatial scales. Coral Reefs 23:235-244

Choat JH, Robertson DR (2002) Age-based studies. In: Sale PF (ed) Coral reef fishes: dynamics and diversity in a complex ecosystem. Academic Press, San Diego, CA, p 57-80

Choat JH, Robbins WD, Clements KD (2004) The trophic status of herbivorous fishes on coral reefs. Mar Biol 145: $445-454$

Clarke KR (1993) Non-parametric multivariate analyses of changes in community structure. Aust J Ecol 18:117-143

Connell JH (1997) Disturbance and recovery of coral assemblages. Coral Reefs 16:101-113

Dawson-Shepherd AR, Warwick RM, Clarke KR, Brown BE (1992) An analysis of fish community responses to coral mining in the Maldives. Environ Biol Fish 33:367-380

Friedlander AM, Parrish JD (1998) Habitat characteristics affecting fish assemblages on a Hawaiian coral reef. J Exp Mar Biol Ecol 224:1-30

Froese R, Pauly D (eds) (2005) FishBase, Version 3/2005. Available from www.fishbase.org

Garpe KC, Öhman MC (2003) Coral and fish distribution patterns in Mafia Island Marine Park, Tanzania: fish-habitat interactions. Hydrobiologia 498:191-211

Gladstone W (1994) Lek-like spawning, parental care and mating periodicity of the triggerfish Pseudobalistes flavimarginatus (Balistidae). Environ Biol Fish 39:249-257

Gratwicke B, Speight MR (2005) Effects of habitat complexity on Caribbean marine fish assemblages. Mar Ecol Prog Ser 292:301-310

Guzman HM, Robertson DR (1989) Population and feeding responses of the corallivorous pufferfish Arothron meleagris to coral mortality in the eastern Pacific. Mar Ecol Prog Ser 55:121-131

Halford A, Cheal AJ, Ryan D, Williams DMcB (2004) Resilience to large-scale disturbance in coral and fish assemblages on the Great Barrier Reef. Ecology 85:1892-1905

Hart AM, Klumpp DW, Russ GR (1996) Response of herbivorous fishes to crown-of-thorns starfish Acanthaster planci outbreaks. 2. Density and biomass of selected species of herbivorous fish and fish-habitat correlations. Mar Ecol Prog Ser 132:21-30

Hixon MA, Beets JP (1993) Predation, prey refuges and the 
structure of coral-reef fish assemblages. Ecol Monogr 63: $77-101$

Hoegh-Guldberg O (2004) Coral reefs in a century of rapid change. Symbiosis 37:1-31

Hughes TP, Baird AH, Bellwood DR, Card M and 13 others (2003) Climate change, human impacts, and the resilience of coral reefs. Science 301:929-933

Hughes TP, Bellwood DR, Folke C, Steneck RS, Wilson J (2005) New paradigms for supporting the resilience of marine systems. Trends Ecol Evol 20:380-386

Jones GP (1991) Post recruitment processes in the ecology of coral reef fish populations: a multifactorial perspective. In: Sale PF (ed) The ecology of fishes on coral reefs. Academic Press, San Diego, CA, p 294-328

Jones GP, Syms C (1998) Disturbance, habitat structure and the ecology of fishes on coral reefs. Aust J Ecol 23:287-297

Jones GP, McCormick MI, Srinivasan M, Eagle JV (2004) Coral decline threatens fish biodiversity in marine reserves. Proc Natl Acad Sci USA 101:8251-8253

Kokita T, Nakazono A (2001) Rapid response of an obligately corallivorous filefish Oxymonacanthus longirostris (Monacanthidae) to a mass coral bleaching event. Coral Reefs 20: 155-158

Lecchini D, Adjeroud M, Pratchett MS, Cadoret L, Galzin R (2005) Spatial structure of coral reef fish communities in the Ryukyu Islands, southern Japan. Oceanol Acta 26: $537-547$

Lewis AR (1997) Effects of experimental coral disturbance on the structure of fish communities on large patch reefs. Mar Ecol Prog Ser 161:37-50

Lindahl U (1998) Low-tech rehabilitation of degraded coral reefs through transplantation of staghorn corals. Ambio 27:645-650

Lindahl U, Öhman MC, Schelten CK (2001) The 1997/1998 mass mortality of corals: effects on fish communities on a Tanzanian coral reef. Mar Pollut Bull 42:127-131

McClanahan T, Polunin N, Done T (2002a) Ecological states and the resilience of coral reefs. Conserv Ecol 6(2):18 (available at http://www.consecol.org/vol6/iss2/art18/)

McClanahan T, Maina J, Pet-Soede L (2002b) Effects of the 1998 coral mortality event on Kenyan coral reefs and fisheries. Ambio 31:543-550

McCook LJ (2001) Competition between coral and algal turfs along a gradient of terrestrial runoff in the nearshore central Great Barrier Reef. Coral Reefs 19:419-425

McManus JW, Polsenberg JF (2004) Coral-algal phase shifts on coral reefs: ecological and environmental aspects. Prog Oceanogr 60:263-279

McPhaden MJ (1999) El Niño: the child prodigy of 1997-98. Nature 398:559-562

Munday PL (2004) Habitat loss, resource specialization, and extinction on coral reefs. Global Change Biol 10:1642-1647

Nakagawa S (2004) A farewell to Bonferroni: the problems of low statistical power and publication bias. Behav Ecol 15: 1044-1045

Ninio R, Meekan MG, Done TJ, Sweatman H (2000) Temporal patterns in coral assemblages on the Great Barrier Reef from local to large spatial scales. Mar Ecol Prog Ser 194:65-74

Nyström M, Folke C, Moberg F (2000) Coral reef disturbance and resilience in a human dominated environment. Trends Ecol Evol 15:413-417

Öhman MC, Rajasuriya A (1998) Relationships between habitat structure and fish communities on coral and sandstone reefs. Environ Biol Fish 53:19-31

Öhman MC, Rajasuriya A, Olafsson E (1997) Reef fish assemblages in north-western Sri Lanka: distribution patterns, influences of fishing practices. Environ Biol Fish 49:45-61
Öhman MC, Munday PL, Jones GP (1998a) Settlement strategies and distribution patterns of coral-reef fishes. J Exp Mar Biol Ecol 225:219-238

Öhman MC, Rajasuriya A, Svensson S (1998b) The use of butterflyfishes (Chaetodontidae) as bioindicators of habitat structure and human disturbance. Ambio 27:708-716

Pratchett MS, Wilson K, Berumen ML, McCormick MI (2004) Sublethal effects of coral bleaching on an obligate coral feeding butterflyfish. Coral Reefs 23:352-356

Riegl B (2001) Inhibition of reef framework frequent disturbance: examples from the Arabian Gulf, South Africa, and the Cayman Islands. Palaeogeogr Palaeoclimatol Palaeoecol 175:79-101

Riegl B (2002) Effects of the 1996 and 1998 positive sea-surface temperature anomalies on corals, coral diseases and fish in the Arabian Gulf (Dubai, UAE). Mar Biol 140:29-40

Roberts CM, Ormond RFG (1987) Habitat complexity and coral reef fish diversity and abundance on Red Sea fringing reefs. Mar Ecol Prog Ser 41:1-8

Sale PF, Guy JA, Steel WJ (1994) Ecological structure of assemblages of coral reef fishes on isolated patch reefs. Oecologia 98:83-99

Sano M (2000) Stability of reef fish assemblages: responses to coral recovery after catastrophic predation by Acanthaster planci. Mar Ecol Prog Ser 198:121-130

Sano M (2004) Short-term effects of a mass coral bleaching event on a reef fish assemblage at Iriomote Island, Japan. Fish Sci 70:41-46

Sano M, Shimizu M, Nose Y (1984) Changes in structure of coral reef fish communities by destruction of hermatypic corals: observational and experimental views. Pac Sci 38: $51-79$

Sano M, Shimizu M, Nose Y (1987) Long term effects of destruction of hermatypic corals by Acanthaster planci infestation on reef communities at Iriomote Island, Japan. Mar Ecol Prog Ser 37:191-199

Spalding MD, Jarvis GE (2002) The impact of the 1998 coral mortality on reef fish communities in the Seychelles. Mar Pollut Bull 44:309-321

Syms C (1998) Disturbance and the structure of coral reef fish communities on the reef slope. J Exp Mar Biol Ecol 230: 151-167

Syms C, Jones GP (2000) Disturbance, habitat structure, and the dynamics of a coral-reef fish community. Ecology 81: 2714-2729

Warwick RM, Clarke KR (1993) Increased variability as a symptom of stress in marine communities. J Exp Mar Biol Ecol 172:215-226

Wass RC (1987) Influence of Acanthaster-induced coral kills on fish communities at Fagatele Bay and at Kape Larsen. In: Birkeland C, Randall RH, Wass RC, Smith BD, Wilkins $\mathrm{S}$ (eds) Biological assessment of the Fagatele Bay National Marine Sanctuary. US Department of Commerce, Washington, DC, p 193-209

Wellington GM, Victor BC (1985) El Niño mass coral mortality: a test of resource limitation in a coral reef damselfish population. Oecologia 68:15-19

Wilkinson C (2000) Status of coral reefs of the world: 2000. Global Coral Reef Monitoring Network and Australian Institute of Marine Science, Townsville, Australia

Williams DM (1986) Temporal variation in the structure of reef slope fish communities (central Great Barrier Reef): short term effects of Acanthaster planci infestation. Mar Ecol Prog Ser 28:157-164

Wilson S, Bellwood DR (1997) Cryptic dietary components of territorial damselfishes (Pomacentridae, Labroidei). Mar Ecol Prog Ser 153:299-310 